\title{
URGENSI PEMBENTUKAN BADAN PENYELESAIAN SENGKETA KONSUMEN DI KABUPATEN BEKASI PROVINSI JAWA BARAT
}

\author{
Medi Nopiana ${ }^{1)}$ \\ Agus Maulana ${ }^{2}$ \\ ${ }^{1}$ Fakultas Ekonomi dan Bisnis Universitas Singaperbangsa Karawang \\ Email:medinopiana@gmail.com \\ ${ }^{2}$ Sekolah Bisnis, Institut Pertanian Bogor \\ Email: agus.maulana0508@gmail.com
}

\begin{abstract}
This research aims to formulate and to analyze the urgency of the establishment of Consumer Dispute Resolution Body (BPSK) in Regency of Bekasi. The method of analysis uses descriptive analysis of both qualitative and quantitative. Meanwhile, the method of data collection is done through literature studies and in-depth interviews. The results show that the urgency of the formation of BPSK in Regency of Bekasi is based on variety of reasons. First, BPSK as a government agency is established to respond to the mandate of Act No. 81999 to form the agency in each regency.

Secondly, BPSK is formed to anticipate the momentum of the ASEAN Economic Community. Thirdly, it is also founded to react to the improvement of economic development in Regency of Bekasi, which is accompanied by the increasing level of prosperity and the level of community awareness of the rights of workers as consumers. Fourth, BPSK is constructed based on the experience of other regions which shows that consumers are in dire need of a neutral government body formed to protect the interests of consumers if they get unfair treatment from business actors. As the same time, business actors also require the same body that can objectively and impartially handle cases involving their business activities.
\end{abstract}

Keywords: Consumer Protection, BPSK, Regency of Bekasi

\section{PENDAHULUAN}

Pesatnya perkembangan per-ekonomian selama beberapa dekade terakhir telah menyebabkan meningkatnya jumlah penduduk berpenghasilan menengah di Indonesia. Peningkatan jumlah penduduk berpenghasilan menengah juga berarti meningkatnya daya beli masyarakat konsumen. Meningkatnya jumlah konsumen yang memiliki daya beli yang besar ini, menjadi peluang pasar yang sangat menggiurkan bagi pelaku usaha (produsen) barang maupun jasa. Kondisi tersebut tidak hanya dilirik oleh pelaku usaha di dalam negeri, tetapi juga oleh pelaku usaha dari berbagai negara.

Sejalan dengan peningkatan daya beli, sikap kritis konsumen terhadap pelaku usaha, khususnya berkenaan dengan mutu layanan dan produk yang dipasarkan, juga meningkat. Perilaku pelaku usaha yang dirasakan kurang tepat serta kualitas produk yang tidak sesuai harapan, seringkali mengundang keluhan konsumen dan dapat menjadi pemicu terjadinya perselisihan antara konsumen dan pelaku usaha.

Sementara itu, hubungan antara pelaku usaha dengan konsumen kerap kali menjadikan konsumen berada pada pihak yang lemah.
Ketidakseimbangan hubungan antara pelaku usaha dengan konsumen tersebut, antara lain disebabkan oleh adanya ketidak-setaraan informasi (asymmetric information) dan ketimpangan daya-tawar (power imbalances), rendahnya kualitas pelayanan kepada konsumen, rendahnya tingkat kesadaran konsumen akan hak-hak mereka, dan kurang efektifnya mekanisme yang tersedia untuk meenyelesaikan sengketa antara pelaku usaha dengan konsumen. Dengan memahami kondisi seperti tersebut, perlu dibangun suatu budaya perlindungan konsumen yang menjadi tanggung jawab dan perhatian semua pihak.

Kehadiran Undang-undang Nomor 8 Tahun 1999 tentang Perlindungan Konsumen diharapkan dapat memberikan iklim yang sehat dalam aspek perlindungan konsumen di Indonesia. Sebagaimana ditegaskan dalam undang-undang tersebut pada pasal 1 angka 1 , bahwa yang dimaksud dengan perlindungan konsumen adalah segala upaya yang menjamin adanya kepastian hukum untuk memberi perlindungan kepada konsumen. Konsumen memiliki hak untuk mendapatkan advokasi, perlindungan, dan upaya penyelesaian konsumen secara patut. Untuk menjamin hak 
tersebut pemerintah diamanatkan untuk membentuk Badan Penyelesaian Sengketa Konsumen (BPSK) di daerah tingkat II sebagai badan penyelesaian di luar pengadilan untuk kepentingan perlindungan terhadap konsumen.

Di sisi lain, peluang pasar yang besar berimplikasi memperbesar frekuensi dan volume transaksi antara pelaku usaha dan konsumen di Indonesia. Pada gilirannya kemungkinan terjadinya perselisihan pun menjadi tinggi. Kondisi tersebut membutuhkan kesiapan sarana/prasarana yang memadai, selain peraturan juga keterlibatan dari pemerintah sebagai regulator, pelaku usaha, konsumen dan BPSK. Pembentukan BPSK diharapkan dapat meningkatkan kepercayaan konsumen kepada lembaga bentukan pemerintah sebagai pilihan konsumen dalam menyelesaikan sengketa yang berkaitan dengan hak-hak mereka di luar pengadilan. Dari aspek kepentingan masyarakat, keberadaan BPSK diharapkan turut berperan serta untuk membangun masyarakat yang kritis dan peduli terhadap perlindungan konsumen. Pihak pelaku usaha pun diharapkan akan menikmati manfaat dari keberadaan BPSK karena lembaga ini dapat berperan sebagai penengah ketika terjadi perselisihan pelaku usaha dengan konsumen. Selain itu, keberadaan BPSK juga diharapkan dapat menciptakan keseimbangan hubungan antara pelaku usaha dengan konsumen, sehingga dapat mendukung terciptanya iklim usaha yang sehat.

\section{TINJAUAN LITERATUR}

Dasar hukum pembentukan BPSK adalah Undang-undang Perlindungan Konsumen (UUPK) Pasal 49 Ayat (1) jo Pasal 2 Kemenperindag No.350/MPP/ Kep/12/2001 yang mengatur bahwa di setiap kota atau kabupaten harus dibentuk BPSK (Nugroho, 2008). Kehadiran BPSK mulai diresmikan pada tahun 2001, yaitu dengan adanya Keputusan Presiden Nomor 90 Tahun 2001 tentang Pembentukan Badan Penyelesaian Sengketa Konsumen pada Kota Medan, Kota Palembang, Kota Jakarta Pusat, Kota Jakarta Barat, Kota Bandung, Kota Semarang, Kota Yogyakarta, Kota Surabaya, Kota Malang dan Kota Makasar. UUPK merupakan suatu terobosan dalam memfasilitasi para konsumen yang merasa dirugikan dengan mengajukan gugatan ke pelaku usaha di luar pengadilan melalui BPSK. Lebih lanjut, BPSK itu sendiri merupakan pengadilan khusus konsumen (small claim court) yang sangat diharapkan dapat menjawab tuntutan masyarakat agar proses berperkara berjalan cepat, sederhana dan murah (Kristiyanti, 2008).

Badan ini memiliki anggota dari unsur pemerintah, konsumen dan pelaku usaha. Setiap unsur tersebut berjumlah tiga orang atau sebanyak-banyaknya lima orang, yang seluruhnya diangkat dan diberhentikan oleh menteri yang memiliki ruang lingkup tugas dan tanggung jawab di bidang perdagangan. Keanggotaan badan ini terdiri atas Ketua merangkap Anggota, Wakil Ketua merangkap Anggota dan Anggota dibantu oleh suatu sekretariat (Pasal 50 jo 51 UUPK). Dikarenakan lembaga ini berada di luar pengadilan dan telah dipisahkan dari lingkup peradilan, namun kenyataannya pada pasal-pasal tertentu dalam UUPK tetap memberikan penghubung dengan badan peradilan. Dengan demikian lembaga ini tidak bisa dilepaskan begitu saja dari sistem peradilan umum, baik perdata maupun pidana. Keterkaitan BPSK dengan peradilan umum dapat dilihat dari tiga hal (Wisnubroto dalam Nugroho, 2008), yaitu:

a. Para pihak yang menolak putusan BPSK dapat mengajukan keberatan pada Pengadilan Negeri (Pasal 56 ayat (2) UUPK jo Pasal 41 ayat (3) Kemenperindag No.350/MPP/Kep/12/ 2001. Selanjutnya, jika para pihak masih berkeberatan terhadap putusan Pengadilan Negeri tersebut, dapat mengajukan Kasasi ke Mahkamah Agung (pasal 58 UUPK).

b. Apabila pelaku usaha menerima putusan tersebut atau tidak mengajukan keberatan terhadap putusan BPSK, tetapi enggan melaksanakan kewajibannya, maka BPSK menyerahkan putusan tersebut kepada penyidik untuk melakukan penyidikan sesuai dengan ketentuan undang-undang yang berlaku (Pasal 56 ayat (4) UUPK jo Pasal 41 ayat (6) Kemenperindag No.350/MPP/Kep/12/ 2001.

c. Putusan BPSK dimintakan penetapan eksekusi pada Pengadilan Negeri di tempat konsumen dirugikan (Pasal 27 UUPK jo Pasal 42 ayat (2) Kemenperindag No. 350/MPP/Kep/12/ 2001.

\section{Tugas dan Wewenang BPSK}

Setiap penyelesaian sengketa konsumen dilakukan oleh majelis yang dibentuk oleh Ketua BPSK dan dibantu oleh Panitera. Susunan majelis BPSK harus ganjil dengan ketentuan minimal 3 orang yang mewakili semua unsur sebagaimana dimaksud dala Pasal 54 ayat (2) UUPK, yaitu unsur pemerintah, konsumen, dan pelaku usaha. Salah satu anggota majelis tersebut wajib berpendidikan dan berpengetahuan di bidang hukum. Ketua Majelis BPSK harus dari unsur pemerintah, walaupun tidak berpendidikan tinggi hukum.

Untuk menangani penyelesaian sengketa konsumen dengan cara konsiliasi atau mediasi, pihak yang berwenang untuk menetapkan personil, baik sebagai Ketua Majelis yang berasal dari unsur pemerintah maupun anggota majelis yang berasal dari unsur konsumen dan pelaku usaha adalah Ketua 
BPSK. Hal ini berbeda dengan majelis yang akan menyelesaikan sengketa konsumen dengan cara arbitrase, Ketua BPSK tidak berwenang untuk menentukan personil yang akan menjadi Ketua Majelis dan Anggota Majelis. Yang berwenang mengajukan personil yang duduk dalam majelis adalah pihak yang bersengketa.

Para pihak dapat memilih arbiter yang mewakili kepentingannya. Konsumen berhak memilih dengan bebas salah satu dari anggora BPSK yang berasal dari unsur konsumen sebagai arbiter yang akan menjadi Anggota Majelis. Demikian pula, pelaku usaha berhak memilih salah satu anggota BPSK yang berasal dari unsur pelaku usaha sebagai arbiter yang akan menjadi Anggota Majelis. Selanjutnya, arbiter hasil pilihan konsumen dan arbiter pilihan pelaku usaha secara bersama-sama akan memilih arbitter ketiga yang berasal dari unsur pemerintah daru anggota BPSK yang akan menjadi Ketua Majelis (Nugroho, 2008).

Lebih lanjut menurut Nugroho (2008), prosedur untuk memilih arbiter hasil pilihan konsumen dan arbiter hasil pilihan pelaku usaha, demikian juga arbiter ketiga dari unsur pemerintah dilakukan dengan mengisi formulir pemilihan arbiter. Hasil pemilihan arbiter setelah dituangkan dalam pengisian formulir pemilihan arbiter akan ditetapkan oleh Ketua BPSK sebagai majelis yang menangani sengketa konsumen dengan cara arbitrase melalui penetapan.

Adapun tugas dan wewenang BPSK sebagai berikut:

1. Melaksanakan penanganan dan penyelesaian sengketa konsumen, dengan cara mediasi, konsiliasi atau arbitrase;

2. Memberikan konsultasi perlindungan konsumen;

3. Melakukan pengawasan terhadap pencantuman klausula baku;

4. Melaporkan kepada penyidik umum jika terjadi pelanggaran ketentuan dalam undang-undang ini;

5. Menerima pengaduan, baik tertulis maupun tidak tertulis dari konsumen tentang terjadinya pelanggaran terhadap perlindungan konsumen;

6. Melakukan penelitian dan pemeriksaan sengketa perlindungan konsumen;

7. Memanggil pelaku usaha yang diduga telah melakukan pelanggaran terhadap perlindungan konsumen;

8. Memanggil dan menghadirkan saksi, saksi ahli, dan/atau setiap orang yang dianggap mengetahui pelanggaran terhadap undangundang ini;

9. Meminta bantuan penyidik untuk menghadirkan pelaku usaha, saksi, saksi ahli, atau setiap orang sebagaimana dimaksud di angka 7 dan 8 yang tidak bersedia memenuhi panggilan BPSK;
10. Mendapatkan, meneliti dan/atau menilai surat, dokumen, atau alat bukti lain guna penyelidikan dan/atau pemeriksaan;

11. Memutuskan dan menetapkan ada atau tidak adanya kerugian di pihak konsumen;

12. Memberitahukan putusan kepada pelaku usaha yang melakukan perlanggaran terhadap perlindungan konsumen;

13. Menjatuhkan sanksi administratif kepada pelaku usaha yang melanggar ketentuan undang-undang ini.

Berdasarkan tugas dan wewenang tersebut, dapat disimpulkan bahwa terdapat 2 fungsi strategis BPSK, sebagai berikut:

1. BPSK berfungsi sebagai instrumen hukum penyelesaian sengketa di luar pengadilan (alternative dispute resolution), yaitu melalui konsoliasi, mediasi dan arbitrase;

2. Melakukan pengawasan terhadap pencantuman klausula baku (Pasal 52 butir c UUPK);

3. Salah satu fungsi strategis ini adalah untuk menciptakan keseimbangan kepentingankepentingan pelaku usaha dan konsumen. Jadi tidak hanya klausula baku yang dikeluarkan oleh pelaku usaha perusahaanperusahaan swasta, tetapi juga pelaku usaha atau perusahaan-perusahaan milik negara.

\section{METODE PENELITIAN}

\section{Metode Pengumpulan Data}

Data dan informasi yang dibutuhkan dalam penelitian ini dikumpulkan melalui penggalian sumber-sumber pustaka dan wawancara mendalam (in-depth interview). Studi pustaka dilakukan pada tahap awal, dengan tujuan untuk memelajari berbagai dokumen hukum, literatur dan kajian sebelumnya yang berkaitan dengan perlindungan konsumen dan pembentukan lembaga BPSK. Hasil studi penelusuran dokumen ini digunakan untuk menyusun pedoman rancangan pertanyaan untuk wawancara mendalam. Wawancara untuk mendapatkan data primer dilakukan kepada narasumber di BPSK Kota Bogor dan Kabupaten Karawang, serta juga kepada para pejabat di lingkungan Pemerintah Kabupaten Bekasi.

Data sekunder yang digunakan untuk analisis utamanya bersumber pada Kabupaten Bekasi dalam Angka dan sumber-sumber lainnya yang berupa:

1. Pendapatan Domestik Regional Bruto (PDRB) sektoral dan pengeluaran dalam lingkup Kabupaten Bekasi, Provinsi Jawa Barat dan nasional;

2. Jumlah penduduk kelas menengah di Kabupaten Bekasi; 
3. Nilai dan pertumbuhan kredit perbankan Kabupaten Bekasi dalam lingkup dan Provinsi Jawa Barat;

4. Indeks Pembangunan Manusia dalam lingkup Kabupaten Bekasi dan Provinsi Jawa Barat, dan lain-lain.

\section{Jenis dan Sumber Data}

Jenis data yang digunakan dalam penelitian ini adalah data primer dan data sekunder. Adapun jenis dan sumber data yang akan dikumpulkan adalah sebagai berikut:

1. Data primer, yaitu data atau informasi yang diperoleh melalui wawancara secara mendalam dengan para pemangku kepentingan terpilih di Kabupaten Bekasi, seperti Badan Perencanaan Pembangunan Daerah dan Dinas Perindustrian, Perdagangan, Koperasi dan Usaha Mikro, Kecil dan Menengah. Selain itu, data primer juga diperoleh melalui kegiatan kunjungan ke BPSK serta Dinas Perindustrian dan Perdagangan di kabupaten/kota lain yang terdekat (Kabupaten Karawang dan Kota Bogor). Pemilihan kabupaten/kota tersebut dengan alasan bahwa jarak keduanya dengan wilayah Kabupaten Bekasi berdekatan, sehingga karakteristik perekonomian dan perilaku masyarakat yang relatif sama, sehingga memudahkan untuk memahami berbagai permasalahan yang terjadi dalam pembentukan BPSK. Data primer dibutuhkan sebagai data atau informasi pendukung untuk membantu lebih memperkaya pembahasan dalam penelitian ini.

2. Data sekunder, merupakan data pendukung yang berasal dari Biro Pusat Statistik, Bank Indonesia, Kementerian Keuangan, Kementerian Perdagangan, Badan Perencanaan Pembangunan Daerah, Dinas Perindustrian, Perdagangan, Koperasi dan Usaha Mikro, Kecil dan Menengah, dan BPSK Kota Bogor dan BPSK Kabupaten Karawang.

\section{Metode Analisis Data}

Dalam penelitian ini, metode analisis data yang digunakan adalah metode analisis deskriptif kualitatif dan kuantitatif. Analisis deskriptif kualitatif dilakukan sebagai berikut:

1. Analisis berbagai sumber hukum, laporanlaporan studi terdahulu, serta data sekunder yang dibutuhkan, antara lain UU No. 8/1999 dan berbagai aturan tentang perlindungan konsumen.

2. Analisis hasil wawancara mendalam dengan berbagai pemangku kepentingan terpilih di Kabupaten Bekasi, antara lain seperti Badan Perencanaan Pembangunan Daerah dan Dinas Perindustrian, Perdagangan, Koperasi dan Usaha Mikro, Kecil dan Menengah.
3. Analisis hasil wawancara mendalam dalam kunjungan ke BPSK Kota Bogor dan Dinas Perindustrian, Perdagangan, Pertambangan dan Energi Kabupaten Karawang serta BPSK Kabupaten Karawang.

Metode analisis deskriptif kuantitatif dilakukan untuk menemukan kecenderungan berkala dari berbagai data perekonomian serta mengetahui kemungkinan dampaknya atas fenomena sosial yang berkembang di kalangan masyarakat Kabupaten Bekasi.

\section{PEMBAHASAN}

Berdasarkan hasil studi pustaka dan wawancara mendalam, urgensi pembentukan BPSK di Kabupaten Bekasi sebagai berikut.

\section{Amanat Undang-Undang No. 8 Tahun 1999}

Pembentukan BPSK di berbagai kabupaten/kota telah jelas disebutkan dalam Pasal 49 ayat (1) Undang-undang No.8 Tahun 1999 tentang Perlindungan Konsumen, bahwa "Pemerintah membentuk badan penyelesaian sengketa konsumen di Daerah Tingkat II untuk penyelesaian sengketa konsumen di luar pengadilan". Pembentukan BPSK di berbagai kabupaten/kota dimaksudkan sebagai upaya merespon dinamika dan kebutuhan perlindungan konsumen yang berkembang dengan cepat di masyarakat. Tanpa mengesampingkan peran peradilan umum, proses beracara yang sederhana, waktu yang lebih singkat, dan biaya yang murah menjadikan BPSK sebagai lembaga di kabupetan/kota yang lebih memberikan harapan bagi masyarakat untuk menyelesaikan sengketa antara konsumen dan pelaku usaha.

Sementara itu berdasarkan data Kementerian Perdagangan, pada 2013 terdapat 886 pengaduan telah diterima oleh 28 BPSK. Pengaduan-pengaduan tersebut terdiri dari 168 pengaduan kasus barang dan 718 pengaduan kasus jasa. Dari jumlah tersebut, sebanyak 686 kasus telah diselesaikan dengan cara mediasi 43,68\%, konsiliasi 5,98\%, dan arbitrase 27,76\%. Adapun pengaduan yang ditolak karena ketidaklengkapan data atau tidak dalam lingkup wewenang BPSK sebanyak 105 kasus, dan yang sedang dalam proses sebanyak 86 kasus (Kementerian Perdagangan Republik Indonesia, 2014).

\section{Momentum Bergulirnya Masyarakat Ekonomi ASEAN}

Mulai tahun 2015, Indonesia akan dihadapkan pada integrasi ekonomi di wilayah Asia Tenggara dalam kerangka Masyarakat Ekonomi ASEAN (MEA) atau ASEAN Economic Community (AEC). Dalam momentum tersebut, arus barang, jasa, dan modal akan semakin terbuka di antara negara- 
negara anggota ASEAN. Kondisi tersebut kemungkinan besar akan mengakibatkan membanjirnya ketersediaan barang-barang impor di pasar domestik Indonesia. Upayaupaya peningkatan perlindungan konsumen diperlukan, agar masyarakat dapat mendapatkan produk dan jasa yang aman dengan harga yang kompetitif.

Dalam mengantisipasi momentum tersebut, Pemerintah Pusat (dalam hal ini Kementerian Perdagangan) terus mendorong pemerintah kabupaten/kota (termasuk Kabupten Bekasi) untuk membangun infrastruktur perlindungan konsumen, antara lain melalui pembentukan BPSK. Pentingnya pembentukan BPSK di Kabupaten Bekasi sejalan dalam mendukung target Pemerintah Pusat untuk membentuk 50 BPSK di berbagai kabupaten/kota setiap tahunnya. Jumlah BPSK di Indonesia saat ini masih jauh dari ideal, sehingga belum mampu memenuhi kebutuhan masyarakat di daerah. Sampai dengan tahun 2014, jumlah BPSK yang terbentuk melalui Keputusan Presiden telah berjumlah 124 BPSK. Dari jumlah tersebut, sebanyak 71 BPSK telah memiliki anggota berdasarkan Keputusan Menteri Perdagangan dan sebanyak 60 BPSK telah memiliki anggota sekretariat (Kementerian Perdagangan Republik Indonesia, 2014).

\section{Perkembangan Ekonomi Kabupaten Bekasi}

Makin membaiknya perkembangan perekonomian di kabupaten ini ditandai oleh sejumlah pencapaian yang mengesankan. Di antaranya, perekonomian Kabupaten Bekasi mencatat nilai PDRB terbesar di antara kabupaten/kota di Jawa Barat. Selain itu, laju pertumbuhan ekonomi kabupaten ini selalu berada di atas pertumbuhan ekonomi nasional. Dengan berbagai kemajuan tersubut, Kabupaten Bekasi harus memiliki berbagai infrastruktur publik yang memenuhi segala kebutuhan masyarakatnya, agar tidak tertinggal oleh kabupaten/kota lainnya. Salah satunya adalah pembentukan BPSK Kabupaten Bekasi, dalam rangka upaya menegakkan hak-hak konsumen, sekaligus memacu terciptanya iklim ekonomi yang kondusif.

\section{a. Nilai PDRB dan Laju Pertumbuhan Ekonomi Kabupaten Bekasi}

PDRB menggambarkan kemampuan suatu wilayah untuk menciptakan output (nilai tambah) pada suatu waktu tertentu. Berdasarkan data Badan Pusat Statistik, nilai PDRB Kabupaten Bekasi pada tahun 2015 merupakan yang terbesar di antara kabupaten/kota di Jawa Barat. Nilai PDRB kabupaten ini atas dasar harga berlaku mencapai Rp 246.046,15 miliar pada tahun tersebut. Nilai PDRB Kabupaten Bekasi melampaui PDRB Kota Bandung dan
Kabupaten Bogor, masing-masing mencapai Rp 195.809 miliar dan Rp 168.095,24 miliar.

Di samping itu, laju pertumbuhan ekonomi kabupaten ini pada periode 2011-2015 mencatat perkembangan yang mengesankan. Hampir setiap tahun laju pertumbuhan ekonomi Kabupaten Bekasi berada di atas pertumbuhan ekonomi nasional. Berdasarkan data Badan Pusat Statistik, pertumbuhan ekonomi nasional pada kurun 2011-2015 masing-masing adalah 6,17 persen, 6,03 persen, 5,56 persen, 5,02 persen dan 4,79 persen. Sedangkan pertumbuhan ekonomi Kabupaten Bekasi dalam kurun waktu yang sama berturut-turut mencapai 6,60 persen, 6,53 persen, 6,23 persen, 5,88 persen dan 4,46 persen. Hal ini mengindikasikan bahwa pertumbuhan ekonomi yang tinggi yang dicapai kabupaten ini sangat berguna untuk meningkatkan kesejahteraan, memperluas kesempatan kerja, meningkatkan produktivitas dan memperbaiki ketimpangan distribusi pendapatan masyarakatnya.

\section{b. Besarnya Kontribusi terhadap PDRB dan Pertumbuhan Sektor Perdagangan di Kabupaten Bekasi}

Pesatnya perkembangan di sektor industri memberikan pengaruh yang berarti terhadap pergerakan ekonomi di sektor perdagangan Kabupaten Bekasi. Pada tahun 2015, kontribusi sektor perdagangan besar dan eceran serta reparasi mobil dan seperda motor terhadap pembentukan PDRB sebesar 5,41 persen, merupakan kontribusi tertinggi ketiga setelah sektor industri pengolahan dan konstruksi. Sementara itu, output dari arus barang hasil industri serta multiplier effect dari adanya kegiatan industri menjadikan sektor perdagangan besar dan eceran serta reparasi mobil dan seperda motor tumbuh sebesar 4,10 persen pada tahun yang sama (berdasarkan data Badan Pusat Statistik atas dasar harga konstan).

\section{c. Tingginya Nilai dan Pertumbuhan Penyaluran Kredit Perbankan di Kabupaten Bekasi}

Ditinjau dari nilai penyaluran kredit perbankan, Kabupaten Bekasi merupakan yang tertinggi di antara kabupaten/kota di Jawa Barat. Berdasarkan data Badan Pusat Statistik, posisi penyaluran kredit oleh bank umum dan BPR di Kabupaten Bekasi pada tahun 2015 mencapai Rp 97,36 triliun, melebihi posisi penyaluran kredit di Kota Bandung Rp 87,30 triliun dan Kabupaten Bandung Rp 47,44 triliun. Nilai penyaluran kredit tersebut menyumbang pangsa 18,25 persen dati total penyaluran kredit di Jawa Barat, melebihi Kota Bandung (16,48 persen) dan Kabupaten Bandung (8,98 persen). Sedangkan dari sisi pertumbuhan kredit, berdasarkan data Bank Indonesia kredit yang disalurkan oleh bank yang berkantor di wilayah 
Kabupaten Bekasi pada periode 2011-2015 tumbuh cukup tinggi rata-rata sebesar 17,45 persen.

Kuatnya pengeluaran konsumsi rumah tangga dapat terlihat dari besarnya nilai penyaluran kredit konsumsi oleh bank umum dan BPR yang berkantor di wilayah Kabupaten Bekasi. Nilai kredit konsumsi yang disalurkan mencapai Rp 32,41 triliun pada tahun 2015, meningkat hampir dua kali lipat dibanding tahun 2011 sebesar Rp 16,50 triliun. Posisi kredit tersebut di kabupaten ini mengungguli posisi kredit konsumsi yang disalurkan bank umum dan BPR yang berkantor di wilayah Kota Bandung dan Kabupaten Bogor, masing-masing sebesar Rp 28,04 triliun dan Rp 23,40 triliun. Nilai kredit konsumsi yang disalurkan termasuk Kredit Pemilikan Rumah (KPR) dan kredit pemilikan kendaraan bermotor, yang sangat berpotensi menimbulkan sengketa antara pihak pelaku usaha (lembaga keuangan/perusahaan properti) dengan konsumen atau debiturnya. Dengan demikian, keberadaan BPSK di Kabupaten Bekasi sudah sangat diperlukan untuk memberi alternatif kepada masyarakat (khususnya masyarakat berpenghasilan rendah) dalam menyelesaikan masalah sengketa konsumen dengan pelaku usaha.

\section{Tingkat Kesejahteraan Masyarakat Kabupaten Bekasi}

Pesatnya perkembangan perekonomian di kabupaten ini berdampak pada meningkatnya kesejahteraan masyarakat. Indikasi meningkatnya kesejahteraan masyarakat Kabupaten Bekasi dapat dilihat dari besarnya pendapatan perkapita (PDRB perkapita), proporsi pengeluaran konsumsi masyarakat terhadap barang nonpangan serta besarnya Indeks Pembangunan Manusia (IPM). Hal ini menuntut Pemerintah Daerah untuk menyediakan berbagai infrastruktur publik yang diperlukan masyarakat, termasuk membentuk BPSK Kabupaten Bekasi.

\section{a. Pendapatan Perkapita Kabupaten Bekasi}

Dalam literatur ekonomi makro, tingkat kesejahteraan diukur dengan PDB perkapita atau PDRB perkapita. Makin tinggi PDB perkapita atau PDRB perkapita, makin sejahtera masyarakat. Agar PDB perkapita atau PDRB perkapita terus meningkat, maka perekonomian harus bertumbuh dan harus lebih tinggi dibanding tingkat pertambahan penduduk.

Berdasarkan data Badan Pusat Statistik, PDRB perkapita Kabupaten Bekasi pada tahun 2015 merupakan yang tertinggi kedua di Provinsi Jawa Barat setelah Kota Bandung (Rp 78,91 juta), yakni mencapai Rp 75,80 juta (atas dasar harga berlaku). Disusul PDRB perkapita Kabupaten Karawang Rp 73,51 juta dan
Kabupaten Purwakarta Rp 54,41 juta pada tahun yang sama. Tingginya PDRB perkapita kabupaten Bekasi menunjukkan tingginya tingkat kesejahteraan yang dicapai masyarakat Kabupaten Bekasi dibanding kabupaten/kota dalam satu provinsi. Di sisi lain, tingginya PDRB perkapita Kabupaten Bekasi dapat mendorong makin tingginya pendapatan daerah, khususnya dari pajak dan retribusi. Hal ini dapat meningkatkan kemampuan Pemerintah Daerah dalam membiayai anggaran untuk membangun dan mengoperasionalkan infrastruktur publik, termasuk BPSK.

\section{b. Porsi Pengeluaran Konsumsi Masyarakat untuk Barang Nonpangan}

Secara teoritis, pergeseran pola pengeluaran untuk konsumsi dari makanan ke nonmakanan dapat dijadikan indikator peningkatan kesejahteraan. Dengan demikian, semakin tingginya porsi pengeluaran nonmakanan dapat mengindikasikan adanya perbaikan tingkat kesejahteraan. Berdasarkan data Badan Pusat Statistik, mulai tahun 2013 masyarakat Kabupaten Bekasi mengalokasikan lebih dari separuh pendapatannya (yakni 52,69 persen) digunakan untuk untuk konsumsi nonmakanan (nonpangan). Kondisi tersebut menunjukkan tingginya kesejahteraan masyarakat Kabupaten Bekasi yang dicapai pada beberapa tahun terakhir. Hal ini mengakibatkan makin tingginya masyarakat menggunakan produk-produk yang dihasilkan pelaku usaha (produsen), pada gilirannya diduga akan berdampak pada makin tingginya potensi perselisihan antara pelaku usaha dengan konsumen. Produk-produk yang berpotensi tinggi menimbulkan perselisihan, antara lain seperti produk lembaga keuangan dan properti.

\section{c. Besarnya IPM}

Indeks ini menunjukkan gambaran komprehensif mengenai tingkat pencapaian pembangunan manusia sebagai dampak dari kegiatan pembangunan yang dilakuan oleh suatu negara/daerah. Semakin tinggi nilai IPM suatu negara/daerah, menunjukkan pencapaian pembangunan manusianya semakin baik. Indikator ini juga tidak lepas dari masalah pencapaian kesejahteraan yang telah dicapai suatu negara/daerah.

Berdasarkan data Badan Pusat Statistik, pencapaian IPM Kabupaten Bekasi menempati peringkat ke-8 dari 27 kabupaten/kota di Provinsi Jawa Barat, yakni sebesar 71,19 pada tahun 2015. Hal ini menunjukkan cukup tingginya kualitas sumber daya manusia masyarakat Kabupaten Bekasi. Pada gilirannya akan berdampak pada tingginya tingkat produktivitas dan kesejahteraan masyarakat.

Selain dibanding dengan Kota Bekasi dan DKI Jakarta, pencapaian ini merupakan yang tertinggi dibanding kabupaten tetangganya, 
Kabupaten Karawang $(67,66)$ dan Kabupaten Bogor $(67,77)$ pada tahun yang sama. Di samping Kota Bekasi, pencapaian IPM Kabupaten Bekasi juga merupakan tertinggi dibandingkan kabupaten-kabupaten di wilayah bekas Karesidenan Purwakarta, yakni Kabupaten Purwakarta $(67,84)$ dan Subang $(66,52)$. Namun demikian, justru keberadaan BPSK lebih dulu ada di kabupaten-kabupaten seperti Kabupaten Karawang, Kabupaten Bogor dan Kabupaten Purwakarta.

\section{Dampak Perkembangan Ekonomi dan Kesejahteraan terhadap Pembentukan Kelas Menengah di Kabupaten Bekasi}

Pesatnya perkembangan perekonomian dan membaiknya tingkat kesejahteraan masyarakat telah berdampak pada meningkatnya jumlah penduduk berpenghasilan menengah (kelas menengah) di Kabupaten Bekasi. Menurut Bank Indonesia (2012), kelompok penduduk kelas menengah dapat didefinisikan sebagai kelompok penduduk dengan tingkat pengeluaran konsumsi antara 2 dolar AS sampai dengan 20 dolar AS per orang per hari. Dalam ulasan-ulasan terkait kelas menengah, penduduk dalam kategori ini dapat dipecah lagi lebih lanjut menjadi (i) kelompok penduduk kelas menengah bawah/baru keluar dari kemiskinan, yaitu kelompok penduduk dengan tingkat pengeluaran konsumsi antara 2 dolar AS - 4 dolar AS per orang per hari, (ii) kelas menengah - menengah, yaitu kelompok penduduk dengan pengeluaran konsumsi antara 4 dolar AS - 10 dolar AS per orang per hari, dan (iii) kelas menengah-atas yaitu kelompok penduduk dengan pengeluaran konsumsi antara 10 dolar AS - 20 dolar AS per orang per hari ${ }^{1}$.

Berdasarkan Tabel 5.1., secara umum jumlah dan persentase kelompok penduduk menengah Kabupaten Bekasi terus mengalami peningkatan ${ }^{2}$. Menurut data Badan Pusat Statistik, jumlah penduduk kelas menengah pada tahun 2011 hanya sebanyak 1,66 juta orang, atau $61,98 \%$ dari jumlah keseluruhan penduduk Kabupaten Bekasi. Jumlah dan persentase kelompok penduduk ini mengalami

\footnotetext{
${ }^{1}$ Kelompok yang tingkat pengeluaran konsumsinya di bawah dari kelompok kelas menengah ini adalah kelompok penduduk yang dikategorikan sebagai kelompok penduduk miskin dan hampir miskin, yaitu kelompok miskin hidup dengan pengeluaran konsumsi di bawah 1,25 dolar AS per orang per hari (garis kemiskinan) dan kelompok hampir miskin yang hidup dengan pengeluaran konsumsi antara 1,25 dolar AS - 2 dolar AS per orang per hari.

2 Indentifikasi kelompok kelas menengah di Kabupaten Bekasi diasumsikan berada pada golongan penduduk yang memiliki pengeluaran perkapita sebulan antara $\mathrm{Rp} 500.000,00-\mathrm{Rp}$ 749.999,00, antara Rp 750.000,00 - Rp 999.999,00, dan Rp 1.000.000 ke atas.
}

peningkatan yang pesat menjadi 2,61 juta pada tahun 2013, atau $87,09 \%$ dari jumlah keseluruhan penduduk Kabupaten Bekasi.

Fenomena peningkatan jumlah dan persentase kelompok penduduk menengah juga membawa perubahan dalam struktur pengeluaran penduduk Kabupaten Bekasi. Hal ini ditunjukkan melalui terjadinya pergeseran jumlah dan persentase kelompok penduduk dari golongan pengeluaran perkapita sebulan antara Rp 500.000,00 - Rp 749.999,00 menuju golongan pengeluaran perkapita sebulan antara Rp 750.000,00 - Rp 999.999,00 dan Rp 1.000 .000 ke atas. Kelompok penduduk Kabupaten Bekasi yang memiliki pengeluaran perkapita sebulan antara Rp 500.000,00 - Rp 749.999,00 terus mengalami penurunan dalam kurun 2011-2013. Sedangkan pada kelompok Rp 750.000,00 - Rp 999.999,00 dan Rp 1.000 .000 ke atas, justru terus mengalami peningkatan.

Kondisi di atas menunjukkan dampak dari pesatnya perkembangan perekonomian dan membaiknya tingkat kesejahteraan masyarakat telah mengakibatkan meningkatnya jumlah dan persentase kelompok penduduk ini. Perbaikan kesejahteraan masyarakat membawa konsekuensi makin tingginya kualitas pendidikan masyarakat, sehingga menumbuhkan sikap kritis masyarakat terhadap produk-produk yang dikonsumsinya. Perilaku tersebut menandai makin meningkatnya kemungkinan sengketa konsumen dengan pelaku usaha. Dengan demikian, keberadaan BPSK di Kabuapaten Bekasi sangat diperlukan untuk mengantisipasi perkembangan tersebut.

\section{PENUTUP}

Berdasarkan pembahasan di atas, dapat disarikan sebagai berikut:

1. Urgensi pembentukan BPSK di Kabupaten Bekasi dilandasi oleh berbagai alasan. Pertama, adanya amanat dalam UndangUndang No. 8 Tahun 1999 untuk membentuk BPSK di setiap kabupaten/kota. Kedua, sebagai antisipasi terhadap momentum bergulirnya Masyarakat Ekonomi ASEAN. Ketiga, makin membaiknya perkembangan ekonomi di Kabupaten Bekasi, yang disertai makin meningkatnya tingkat kesejahteraan dan juga tingkat kesadaran masyarakatnya akan hak-hak mereka sebagai konsumen. Keempat, melihat pengalaman daerah lain, khususnya yang dikaji, tampak bahwa konsumen sangat membutuhkan adanya badan netral bentukan pemerintah untuk melindungi kepentingan konsumen dari perlakuan kurang wajar dari pelaku usaha. Sementara pihak pelaku usaha pun membutuhkan adanya badan yang sama, yang dapat secara obyektif dan tidak 
berpihak menangani kasus-kasus yang melibatkan aktivitas usaha mereka.

2. Perkembangan ekonomi dan kesejahteraan masyarakat berdampak pada meningkatnya masyarakat kelas menengah di Kabupaten Bekasi. Perbaikan kesejahteraan masyarakat selanjutnya berdampak pada makin tingginya kualitas pendidikan masyarakat, sehingga menumbuhkan sikap kritis masyarakat terhadap produk-produk yang dikonsumsinya. Pada gilirannya perilaku tersebut meningkatkan kemungkinan sengketa konsumen dengan pelaku usaha.

\section{DAFTAR PUSTAKA}

Badan Pusat Statistik, 2016, Kabupaten Bekasi Dalam Angka 2015, Katalog BPS: 1102001.3216.

Badan Pusat Statistik, 2016, Statistik Daerah Kabupaten Bekasi 2016, Katalog BPS: 1101002.3216.

Bank Indonesia, 2013, Laporan Perekonomian Tahun 2012, Jakarta.

Badan Perlindungan Konsumen Nasional, 2013, Alternatif Penyelesaian Sengketa Di Luar Pengadilan: "Penguatan BPSK melalui revisi Hukum Acara BPSK", Siaran Pers, tanggal 17 Desember, Tersedia pada http://bpkn.go.id/uploads/document/1570 c795240ebbaa8e4dac32bdacff66d7bca24 0.pdf., Diakses pada tanggal 23 Januari 2017.

Dyarini M., Anggia, 2011, Tanggung Jawab Hukum Pelaku Usaha Perangkat Lunak kepada Konsumen: Kajian Perbandingan Lisensi Standard Software, Bespoke Software dan Customized Software, Tesis, Program Magister Hukum Fakultas Hukum Universitas Indonesia, Jakarta.

Kementerian Perdagangan Republik Indonesia, 2010, Peranan Badan Penyelesaian Sengketa Konsumen (BPSK), Direktorat Perlindungan Konsumen, Direktorat Jenderal Perdagangan Dalam Negeri.

Kementerian Perdagangan Republik Indonesia, 2014, Kemendag Perkuat Upaya Perlindungan Konsumen melalui Bimbingan Teknis SDM, Siaran Pers Pusat Hubungan Masyarakat, tanggal 12 Mei, Tersedia pada http://ditjenpktn.kemendag.go.id/files/pdf /2015/01/12/kemendag-perkuat-upayaperlindungan-konsumen-melaluibimbingan-teknis-sdm-bpsk-id01421036888.pdf, Diakses pada tanggal 23 Januari 2017.
Kotler, Philip, dan Keller, Kevin Lane, 2009, Manajemen Pemasaran Jilid 1, Edisi Ketiga Belas, Jakarta: Penerbit Erlangga.

Kotler, Philip, 1993, Manajemen Pemasaran Analisis, Perencanaan, Implementasi dan Pengendalian Jilid 1, Jakarta: Penerbit Erlangga.

Krisyanti, Cellina Tri Siwi, 2008, Hukum Perlindungan Konsumen, Jakarta: Sinar Grafika.

Marwanti, Dwi Ira, 2010, Upaya Perlindungan Hukum bagi Konsumen melalui BPSK dan Peradilan Umum (Studi tentang Perbandingan Efektivitas Mekanisme Penyelesaian Beberapa Sengketa Konsumen melalui BPSK Provinsi DKI Jakarta dan Pengadilan Negeri Jakarta Pusat), Tesis Program Magister Hukum, Fakultas Hukum Universitas Indonesia, Jakarta.

Nugroho, Susanti Adi, 2008, Proses Penyelesaian Sengketa Konsumen, Jakarta: Praneda Media Group.

Stanton, William J., 2004, Prinsip-Prinsip Pemasaran jilid ke-1, Edisi Ketujuh, Jakarta: Erlangga.

, 2012, Fungsi Dan Peranan BPSK dalam Penyelesaian Sengketa Konsumen, Tersedia pada http://xa.yimg.com/kq/groups/23389461/8 86334908/name/cara., Diakses pada tanggal 23 Januari 2017.

Website :

http://www.jdih.setjen.kemendagri.go.id/\#

http://www.bekasikab.go.id/

http://www.bi.go.id/

http://bps.go.id/

http://bekasikab.bps.go.id/ 
